\title{
Managerial Performance of State Vocational High School Principals in Yogyakarta Special Province, Indonesia
}

\author{
Lia Yuliana, Sugiyono and Lantip Diat Prasojo \\ Universitas Negeri Yogyakarta \\ Yogyakarta, Indonesia
}

\begin{abstract}
This study aimed to analyze the managerial performance of vocational high school principals in managing teachers and academic staff and the obstacles they experienced in the process. The study employed quantitative and qualitative methods. Respondents of the study were ten school supervisors at the Local Office of Ministry of Education and Culture and fifteen vocational high school principals, and 30 vocational high school teachers in Yogyakarta Special Province, Indonesia. Principals and teachers were selected from various vocational high schools through a purposive sampling technique by considering the accreditation ranking of the schools. The data were collected using questionnaire techniques, interviews, and documentation. The data validity was tested using the triangulation of theory, data, and informant review. Afterward, the data were analyzed using qualitative and quantitative data analysis. The results showed that the score of managerial performance based on the evaluation by school supervisors, principals, and teachers was $3.91,4.07$, and 4.10 respectively. The average score of evaluation results of the three groups was 4.05 . The study also found some obstacles experienced by the vocational high school principals in managing teachers and academic staff. These obstacles were the lack of guidance from school supervisors and of funds for teacher management, a limited number of academic staffs, and also the limitation of teaching certification for some teachers.
\end{abstract}

Keywords: principal; managerial performance; human resource management.

\section{Introduction}

The quality of learning in an education system is influenced by the availability of learning facilities and infrastructure, activities, and creativity of teachers and students in the teaching and learning process. Teaching and learning activities will be of high quality if supported by professional teachers who have professional, pedagogical, personal, and social competencies (Law of Teachers 
and Lecturers, Article 10). In addition, it is possible to maximize the quality of learning if qualified students support it (intelligent, highly motivated to learn and have a positive attitude in learning), and supported by adequate learning facilities and infrastructure. Professional teachers will have good teaching performance, while qualified students will have positive behavior in teaching and learning activities. Teaching and learning interactions between teachers and students will surely create a positive and impressive classroom culture or classroom climate that supports the learning process. Thus, all supporting elements of teaching and learning activities must be available to ensure the quality of an instructional program (Cizek, 2000).

Two variables can affect students' learning achievement: the availability and support of inputs and the quality of the learning process. Input consists of students, teachers, and learning facilities and infrastructure. The quality of learning is a measure that shows how high the quality of teacher interaction with students in the learning process in the context of achieving specific goals. Teaching and learning activities are carried out in a particular atmosphere with the support of certain learning facilities and infrastructure, as well. Therefore, the success of the learning process is very dependent on the teacher, students, learning tools, classroom environment, and class culture. All these indicators must support one another in a quality learning activity system (Slamet PH, 2001).

As the school leader, the school principal is the one who determines some factors that can encourage schools to realize their vision, mission, goals, and targets through a variety of programs well-implemented according to the learning plan. Therefore, school principals must have active management and leadership abilities since they have to make decisions quickly and should have a highly positive attitude in improving the quality of their education (Subekhi \& Jauhar, 2012, p. 39). For this purpose, the principal should be able to mobilize or empower all the potential and resources they have for various programs, processes, evaluations, curriculum development, learning activities at schools, teachers' administration, infrastructure, services to students, relations with the community, and the creation of a conducive school climate. These elements will be well implemented when the principal can influence all parties involved in educational activities at school to work together in realizing the school's goals. School principals must be able to move the teachers and administrative staff to carry out the supervision function (Pranita, Kurniah, \& Suprapti, 2018 and Lauma, \& Pido, 2018). The role of the principal, as stated in Permendiknas No. 8 of 2010, is to be responsible for the organization of educational activities, school administration, fostering education personnel, and the utilization and maintenance of infrastructure.

The core task of a school principal is to improve teacher performance (Bredeson, 2000 and Fauzi, Syafrudin, \& Rokhmat, 2018). Furthermore, the success of school improvement depends on the efforts to develop professionalism at schools, especially the development of teacher professionalism (DuFour \& Barkey, 2005). In other words, the principals should devote their efforts to improve the quality 
of learning by continuously developing teacher professionalism. Therefore, the school principal is a famous role model for all activities at school, especially the learning activities in the classroom. Learning improvement in an academic institution can take place continuously and optimally if the teachers' performance as the main actor is improved continually. Therefore, the school principals are demanded to work well, be professional, and be responsive to the aspirations of the school environment and its dynamics and be able to complete tasks effectively and efficiently. Thus, in completing their job, the school principals must be aware of and pay attention to the importance of achieving the institutional goals. The leadership ability of school principals will be very influential in managing teacher professionalism. Poor leadership performance will result in a lack of work motivation for the teachers that affect the teachers' professionalism at work.

The Law of Teachers and Lecturers considers that the teaching and lecturing profession is specialized work field that must be carried out based on the following principles (Article 7 paragraph (1)): (a) having talent, interests, vocations, and idealism; (b) having a commitment to improve the quality of education, being loyal, pious and having a noble character; (c) having academic qualifications and educational background according to work field; (d) having the required competencies in accordance with the duty; (e) being responsible for carrying out professional tasks; (f) receiving an income based on the work performance; ( $\mathrm{g}$ ) having the opportunity to develop professionalism in a sustainable manner by lifelong learning; $(h)$ having guaranteed legal protection in carrying out professional duties; and (i) having professional organizations that have the authority to regulate matters related to teachers' professionalism. On this basis, not everyone, and not even a teacher, can become a professional teacher without going through education and training, either individually or collectively, and passing an examination.

The teacher factor is one of the input components that influence the quality of the learning achievement. The learning process will achieve high quality if supported by all the readiness of the inputs including the maximum teacher performance in teaching and learning activities. The teacher is a very influential factor as seen from the teachers' ability and eligibility to teach. Doherty (2008) explains that the teacher quality factor has a significant correlation to student learning achievement. Likewise, Schacter (2006) explains that teacher performance is an essential input variable to improve students' learning achievement. These studies confirm that the teacher factor is an important variable to improve the quality of the learning process.

Similarly, according to Suyanto \& Jihad (2013, p. 137), the role of teachers is significant in educational activities, since teachers act as educators, instructors, mentors, trainers, advisors, reformers, models and role models, personal, researchers, the one to encourage creativity, generate views, routine workers, camp shifters, story bearer, actor, emancipator, evaluator, preservative, and culminates. Teachers are required to have sufficient competencies: basic (personality), general (teaching ability), and special (development of teaching 
skills) to support these tasks. Basic skills include having faith and piety, having an insight of Pancasila, being fully responsible, being authoritative, being disciplined, being dedicated, socializing with the community, loving students, and caring for their education. General abilities include: 1) mastering education and teacher training; 2) mastering the curriculum; 3) mastering general methodical didactics; 4) mastering classroom management; 5) being able to carry out monitoring and evaluation of students; and 6) being able to develop and self-actualize (Ministry of Education and Culture, 2018, p. 32). Specific abilities include: questioning skills, giving a reinforcement, variations, explaining, opening and closing lessons, guiding small group discussions, managing classes, and teaching small groups and individuals. Based on the given theories and ideas, it is possible to compile the formulation of vocational teacher performance that accommodates the existing differences and is considered as the complete formulation. Competencies to apply in the vocational school teachers' performance include: 1) mastery of the field of study or teaching materials; 2) understanding students' characteristics; 3) mastery of learning management; 4) mastery of learning methods and strategies; 5) mastery of student learning outcomes assessment; and 6) having the personality and insight for professional development (Ritchie, 2013).

Indonesian national education is organized by some systems, levels and different types of education. Education is a platform with which students develop their potential in an educational process that is in line with educational goals (Devi, Devan, Soon, \& Han, 2012). There is three education systems namely, formal, non-formal and informal education system. Formal education is a structured and tiered education system consisting of primary education, secondary education and higher education (Kalolo, 2015). Non-formal education is an education system outside of formal education that can be implemented in a structured and tiered manner. Informal education is the form of education taking place in the family and the surrounding environment (Lee, Mann, \& Frank, 2010 and (Nye \& Hedges, 2004).

These national standards make the direction for improving the quality of Indonesian education become clearer (Akpan \& Ita, 2015). Thus, each academic institution that has reached or exceeded the national standard of education is said to have a good quality of education (Nasution, 2013, p. 98). There are various policies implemented to enhance the quality of education gradually and to reach the top quality (Bansal, 2004). Therefore, standardization of education services assures quality education services. The education quality is determined by the excellent assessment system (Clark, 2009). Goetsch \& Davis (2014, p. 36) defines quality as "a dynamic state associated with products, services, people, processes, and environments that meets or exceeds expectations."

The current generation living in the Industrial Revolution 4.0 requires competencies to be based on information and communication technology. This modern demand positively encourages teachers to upgrade their competencies since educational services should be improved to keep up with the current demand. Otherwise, the existing competencies that are deemed to have met the 
specified standards will no longer be categorized as a standard since the 4.0 era will urge far better optimization of services. To improve competency, we need programs that have an impact on program funding and the availability of infrastructure and other supporting facilities. Therefore, this attempt will highly rely on the availability of existing financing. Teachers must have the full authority to conduct authentic assessments (Azim \& Khan, 2012 and Rourke \& Coleman, 2011).

To meet the demand of the student-centered learning that encourages students' motivation, interest, creativity, initiative, inspiration, independence, and enthusiasm in the learning process, teachers are required to choose learning strategies according to the demands of the learning material. The implementation of this standard is closely related to the teacher (Sugiyo, Kusuma, \& Wahyuni, 2009 and Trinova, 2013). Teachers have difficulty in fulfilling the learning demands of the standard process since the learning process tends to be implemented conventionally. Some factors to inhibit the learning process include the unavailability of media and learning equipment at schools and a large number of students in one class that does not support the application of student-centered active and creative learning. As a result, most teachers apply teacher-centered learning approaches (Listyani, 2007; Musiman, 2011; and Rudatin, 2015). This is in contrast to the fact that teacher professionalism is vital to improve the quality of education (Admiraal, Janssen, Huizenga, Kranenburg, Taconis, \& Corda, 2014, and Frey, Schmitt, \& Allen, 2012).

Indonesian teachers face very different problems. Such problems can be classified based on four teacher competencies: 1) professional competence: teacher skills in preparing learning tools; teacher skills in determining and presenting essential materials; teachers' reliance on student worksheets available in the market, instead of making their teaching materials; theoretical presentation of materials without using the laboratory experiment, 2) pedagogical competence: the inappropriate teaching strategy; less attractive teaching styles for students; the lacking role of educator, instructor and trainer; too many tasks for students, 3) social/interpersonal competence: being less open to peer criticism, and 4) personal/individual competence: inability to emulate teacher affection, lack of applying discipline for students; commitment, lack of performance and sincerity in planning and implementing learning process (Darling-Hammond, 2000).

The development of a school depends on the loyalty, integrity, and responsibility of all components of the school towards improving school quality. The principal as a school leader has an important role and responsibility in managing available resources to improve education quality at the level of the education unit (Stanley, 2016, p. 198). It is expected that there is a match between das sein and das sollen. In other words, the current situation should meet the normal condition. The quality of vocational high schools in Yogyakarta varies from superior status or A level to those that have not been accredited. This reality indicates the urge to reform SMK comprehensively, which is reflected by 
the leadership role of the school principals as the component responsible for the education process.

The data show that 70 vocational schools in Yogyakarta Special Province have not been accredited. Four vocational schools in the province have grade C, 38 schools have grade B, and 105 schools have grade A. Sleman Regency has 120 vocational schools, and most of it has been accredited with grade A. Many private vocational schools in Yogyakarta Special Province have not been accredited. There are 14 schools in Sleman Regency, 17 schools Bantul Regency, and 16 schools in Gunung Kidul Regency that have not been accredited. Yogyakarta City has the best accreditation status, with 100 percent of state vocational high schools accredited with grade A. To obtain an excellent or good accreditation, the school must meet all standards. In this case, the principal has an important task to manage the education unit well to enable the school to achieve National Education Standards. Therefore, the principal is the key to success for the development of school quality in a sustainable manner (Delors, 2016, p. 76). Likewise, it is necessary for various academics and education practitioners to concern about the development of vocational high schools, especially school principals, as program managers.

Indonesian vocational high schools, according to government regulations, should have various functions. However, in some cases, the schools performed very poorly. Vocational High School Statistics 2016, with the data from the 2015/2016 academic year, indicated 8,641 vocational students in Indonesia repeating their academic year and 77,899 students dropping out. Data from each province show that there are 218 public and private vocational schools in Yogyakarta Special Province with the total number of students was 81,297 students. 118 students were repeating their year and 1,031 students dropping out of school (Dinas Pendidikan dan Olahraga DIY, 2018, p. 9). Furthermore, the results of vocational school students' computer-based national exams in Yogyakarta Special Province in 2018 indicate a lower score than that in 2017. It implies the principals as leading managers in these vocational schools have many challenges to improve school quality.

The principal is not only an essential instrument for school development but also an agent of change in an institution towards a more positive direction in a comprehensive manner. This is nothing but related to the performance of the principal in carrying out his task following the existing main duties and functions under applicable laws and regulations. However, the current school quality indicates that in general, the principals' performance is not as what is expected. This is evidenced by several kinds of research on the performance of school principals in Indonesia, revealing a trend that the principals do not show optimal work performance at the education unit level (Syahrul, 2016, p. 28).

The school principals are professional officials in a school institution with the primary duties to manage all school resources to achieve the educational goals (Lunenburg \& Ornstein, 2011, p. 97). The principals are not the school authority in the organizational structure, but rather as the mandate-bearer and a leader who is fully responsible for the progress of a school institution. However, some 
researches indicate that the performance of most school principals is far below encouraging results. School principals are the most crucial input for schools that have an essential task, function, and responsibility in achieving school goals (Armstrong, 2012, p. 71). School goals will be achieved well when the principals have good managerial performances.

As a chief manager at the school level, the principal must be able to empower teachers to become educators to improve the school quality (Robbins \& Alvy, 2015 , p. 273). The teacher is a professional educator with the main task of educating, teaching, guiding, directing, training, assessing, and evaluating students in early childhood, formal, basic, and secondary education. Teachers are the spearhead in the learning process, and thus they have a crucial role in improving the quality of education at schools. Data on the Development of Yogyakarta Special Province public and private vocational schools in 2015, 2016, 2017, and 2018 show that there were more than 6,000 teachers actively involved in academic activities every year. The more significant number of teachers does not necessarily guarantee the quality of education at schools, because the central aspect to concern in the education process is quality. Qualified teachers will also have an impact on the quality improvement of the learning process at schools (Dinas Pendidikan dan Olahraga DIY, 2018, p. 14).

This study addresses the managerial performance of school principals in organizing and empowering the teachers' performance. It also analyzes the obstacles experienced by the principals of vocational high schools in Yogyakarta Special Province in managing teachers and academic staff. To ensure sequenced writing, this study is organized as follows. This section introduces the background of the study along with relevant previous works. The second section explains the method employed in the study. Section three explores the results of the study followed by section four that discusses it. Section five concludes the study and provides insight for future works.

\section{Research Method}

This study uses a mixed quantitative and qualitative method. A quantitative approach is used to find out the managerial performance of vocational school principals in Yogyakarta Special Province in managing teachers, while the qualitative approach is used to explore and analyze the obstacles experienced by the principals of state vocational high schools in Yogyakarta Special Province in managing the teachers. This study involved ten school supervisors at the Local Office of Ministry of Education and Culture, 15 state vocational school principals, and 30 state vocational high school teachers in Yogyakarta Special Province. The respondents were chosen through a purposive sampling technique by considering the accreditation ranking of the school based on the criteria of upper, middle and lower schools. Fifteen state vocational schools were chosen using purposive sampling to ensure representation of each regency in Yogyakarta Special Province. Final 15 schools involved were SMKN 1 Yogyakarta, SMKN 3 Yogyakarta, SMKN 6 Yogyakarta, SMKN I Depok, SMKN I Sayegan, SMKN I Godean, SMKN I Nanggulan, SMKN I Panjatan, SMKN I Temon, SMKN I Wonosari, SMKN 2 Wonosari, SMKN I Nglipar, SMKN 1 
Bantul, SMKN I Sewon, and SMKN 1 Sedayu. A principal and two teachers from the 15 sample schools were respondents for this study. The data were collected using questionnaire techniques, interviews, and documentation. The data validity was tested using the triangulation method of theory, data, and informant review.

The data were analyzed using qualitative and quantitative data analysis. The quantitative data analysis was conducted with statistics, while the qualitative analysis was performed with path analysis models. Considering that this is evaluation research, the analysis applies the following evaluation criteria.

Table 1: Conversion of quantitative to qualitative data

\begin{tabular}{|c|c|}
\hline Score average & Classification \\
\hline$>4.2$ & Very good \\
\hline$>3.5-4.2$ & Good \\
\hline$>2.5-3.4$ & Neutral \\
\hline$>1.5-2.4$ & Bad \\
\hline$\leq 1.4$ & Very bad \\
\hline
\end{tabular}

The readability of assessment instruments of vocational school principals' managerial performance in the management of teaching staff in Yogyakarta Special Province in the feasibility test was validated by 11 people, constituting education evaluation experts (4 experts), education management (4 experts), and psychometric experts ( 3 people). The assessment was based on a score range of 1 to 5 , with a minimum score of 1 and a maximum score of 5 . The average score of the first stage of assessment of the instrument's readability is as follows.

Table 2: Expert assessment on instrument feasibility

\begin{tabular}{|l|l|c|}
\hline No. & \multicolumn{1}{|c|}{ Aspect of assessment } & Average score \\
\hline 1 & Clarity of instrument instructions & 4.55 \\
\hline 2 & Clarity of assessment aspects & 4.45 \\
\hline 3 & Clarity of indicators & 4.18 \\
\hline 4 & Clarity of instruments & 4.45 \\
\hline 5 & Sufficiency of instrument points & 4.27 \\
\hline 6 & The sequence of instrument points & 4.55 \\
\hline 7 & Clarity of language and statements & 4.36 \\
\hline 8 & Correctness of grammar & 4.18 \\
\hline 9 & Usage of standardized language & 4.27 \\
\hline 10 & Understandable statements & 4.18 \\
\hline 11 & Writing form & 4.55 \\
\hline \multicolumn{2}{|l|}{ Total average score } & 4.36 \\
\hline
\end{tabular}

Source: Primary data

Based on the assessment of the 11 experts above, the average score indicates that overall, the instrument is verbally good or appropriate for measuring the managerial performance of state vocational school principals in the management of teaching staff in Yogyakarta Special Province with a mean score of 4.36 or 
excellent category in the score range of $>4.2-5.0$. In addition to conducting an assessment, the validators were also asked to provide comments and input relating to the readability of the instrument. Recommendations of these experts on the readability of the instrument concern the aspects, indicators, systematics, terms, and concepts related to the managerial performance of state vocational school principals in the management of teaching staff. The instrument readability of state vocational school principals' assessment in the management of teaching staff was also assessed by users consisting of school supervisors, principals, and teachers. School supervisors represent the Local Office Ministry of Education and Culture, while school principals and teachers represent the elements of the school. The assessment by users of school supervisors (4 people), school principals (4 people), and teachers (4 people) are as follows.

Table 3: Evaluation of school supervisors, school principals, and teachers on the instrument readability

\begin{tabular}{|l|l|c|}
\hline No. & Aspect of assessment & Average score \\
\hline 1 & Clarity of instrument instructions & 4.50 \\
\hline 2 & Clarity of assessment aspects & 4.33 \\
\hline 3 & Clarity of indicators & 4.42 \\
\hline 4 & Clarity of instruments & 4.33 \\
\hline 5 & Sufficiency of instrument points & 4.50 \\
\hline 6 & The sequence of instrument points & 4.20 \\
\hline 7 & Clarity of language and statements & 4.08 \\
\hline 8 & Correctness of grammar & 4.33 \\
\hline 9 & Usage of standardized language & 4.25 \\
\hline 10 & Understandable statements & 4.50 \\
\hline 11 & Writing form & 4.42 \\
\hline Total average score & 4.35 \\
\hline
\end{tabular}

Source: Primary data

Based on the assessment of the 12 user evaluators above, overall, the mean score indicates that the instrument and its item is reasonable or appropriate to measure the managerial performance of vocational school principals in the management of teachers Yogyakarta Special Province with a mean score of 4.35 or very good categories in the range of $>4.2-5.0$. In addition to assessing the instruments, users were also asked to provide comments and input related to the instrument's readability. The input from the users is related to the quality of the instrument concern with aspects, indicators, systematics, terms, and concepts about the managerial performance of state vocational school principals in the management of teaching staff. The results of expert and user assessments are presented in following table, with a mean score of 4.335, which is included in the excellent category. Therefore, the instrument is suitable for use in this research. 
Table 4: Recapitulation of experts and user assessment on school principals' performance

\begin{tabular}{|l|l|l|}
\hline No. & Assessor & Average score \\
\hline 1 & Experts & 4.36 \\
\hline 2 & Users & 4.35 \\
\hline \multicolumn{2}{|l|}{ Average score } & $\mathbf{4 . 3 5 5}$ \\
\hline
\end{tabular}

Source: Primary data

\section{Results}

After the instrument was declared suitable for use in assessing the managerial performance of vocational school principals in the management of teaching staff in the Special Region of Yogyakarta, the next step was to conduct a field study with ten supervisors from the Local Office of Ministry of Education and Culture. The assessment was carried out by giving an instrument of managerial performance of vocational school principals in the management of teaching staff consisting of 10 items. The assessment uses criteria range of 1-5 with the results shown in table 5 as follows.

Table 5: School supervisor assessment on school principal performance

\begin{tabular}{|l|l|l|}
\hline No. & Aspects & Score \\
\hline 1 & $\begin{array}{l}\text { Develop a management and utilization program for a teacher in } \\
\text { accordance with the vision and mission of the school }\end{array}$ & 4.10 \\
\hline 2 & Formulate targets for improving the quality of teacher & 3.90 \\
\hline 3 & $\begin{array}{l}\text { Formulate strategies for achieving the target of improving the } \\
\text { quality of teacher }\end{array}$ & 4.00 \\
\hline 4 & Implement a management and utilization program for teacher & 3.80 \\
\hline 5 & Develop an instrument for evaluating teacher performance & 3.80 \\
\hline 6 & Assess the performance of teacher & 4.00 \\
\hline 7 & Provide feedback on the performance evaluation of teacher & 3.90 \\
\hline 8 & Evaluating the success of the management and utilization of teacher & 3.80 \\
\hline 9 & $\begin{array}{l}\text { Compile recommendations on the results of evaluations of the } \\
\text { management and utilization of teacher }\end{array}$ & 4.00 \\
\hline 10 & Carry out the follow-up of evaluation results & 3.80 \\
\hline Average & 3.91 \\
\hline
\end{tabular}

Source: Primary data

The assessment of the managerial performance of state vocational school principals in the management of teaching staff shows an average score of 3.91. Thus, the managerial performance of vocational school principals in the management of teaching staff based on the assessment of 10 school supervisors is included in the good category based on the criteria range of $>3.5-4.2$, which is of a good category. All performance indicators in developing academic documents are included in both categories. Besides being assessed by the supervisor, the principal's performance was also assessed by the principals themselves with the following results. 
Table 6: School principals' evaluation on school principals' performance

\begin{tabular}{|l|l|c|}
\hline No. & Aspects & Score \\
\hline 1 & $\begin{array}{l}\text { Develop a management and utilization program for a teacher } \\
\text { following the vision and mission of the school }\end{array}$ & 4.00 \\
\hline 2 & Formulate targets for improving the quality of teacher & 3.93 \\
\hline 3 & $\begin{array}{l}\text { Formulate strategies for achieving the target of improving the } \\
\text { quality of teacher }\end{array}$ & 4.07 \\
\hline 4 & Implement a management and utilization program for teacher & 3.93 \\
\hline 5 & Develop an instrument for evaluating teacher performance & 4.27 \\
\hline 6 & Assess the performance of teacher & 4.13 \\
\hline 7 & Provide feedback on the performance evaluation of teacher & 4.20 \\
\hline 8 & Evaluating the success of the management and utilization of teacher & 3.80 \\
\hline 9 & $\begin{array}{l}\text { Compile recommendations on the results of evaluations of the } \\
\text { management and utilization of teacher }\end{array}$ & 4.00 \\
\hline 10 & Carry out the follow-up of evaluation results & 4.27 \\
\hline Average & 4.07 \\
\hline
\end{tabular}

Source: Primary data

The school principals' assessment of their managerial performance of vocational schools in the management of teaching staff in Yogyakarta Special Province showed a mean score of 4.07. Thus, the managerial performance of state vocational school principals in the management of teaching staff based on the assessment of 15 school principals is included in the good category because it is in the criteria of $>3.5-4.2$, which is a good category. All performance indicators in developing academic documents are included in the good category, except indicator 5, which is to compile an instrument for evaluating the performance of teachers and indicator 10, which is to carry out a follow-up on the evaluation results, each having a mean score of 4.27 . In addition to being assessed by school supervisors and principals, principals' performance was also assessed by teachers with the results presented in table 7 below.

Table 7: Teacher assessment on school principals' performance

\begin{tabular}{|l|l|c|}
\hline No. & Aspects & Score \\
\hline 1 & $\begin{array}{l}\text { Develop a management and utilization program for a teacher in } \\
\text { accordance with the vision and mission of the school }\end{array}$ & 4.03 \\
\hline 2 & $\begin{array}{l}\text { Formulate targets for improving the quality of teacher } \\
\text { Formulate strategies for achieving the target of improving the } \\
\text { quality of teacher }\end{array}$ & 3.97 \\
\hline 4 & Implement a management and utilization program for teacher & 4.20 \\
\hline 5 & Develop an instrument for evaluating teacher performance & 4.07 \\
\hline 6 & Carry out an assessment of the performance of teacher & 4.00 \\
\hline 7 & Provide feedback on the performance evaluation of teacher & 4.23 \\
\hline 8 & Evaluating the success of the management and utilization of teacher & 3.97 \\
\hline 9 & $\begin{array}{l}\text { Compile recommendations on the results of evaluations of the } \\
\text { management and utilization of teacher }\end{array}$ & 4.13 \\
\hline 10 & Carry out the follow-up of evaluation results & 4.17 \\
\hline Average & 4.10 \\
\hline
\end{tabular}

Source: Primary data

The data indicate that the mean score of the teachers' assessment of the managerial performance of state vocational school principals in the management 
of teaching staff in Yogyakarta Special Province is 4.10. Therefore the teachers' assessment of the managerial performance of the state vocational school principals in the management of teaching staff based on the evaluation of 30 teachers is included in the good category because it is in the criteria of $>3.5-4.2$ which is of a good category. All performance indicators in developing academic documents are included in the good category except for indicator 4 , which is implementing the management and utilization program of educators, and indicator 7, which is giving feedback on the evaluation of the teaching staff's performance with each indicator score of 4.23 . Therefore, the mean value of the managerial performance of state vocational school principals in the management of teaching staff is 4.10 or in the good category. In other words, there is no difference between the evaluation of school supervisors, teachers, and the principal's own assessment of the managerial performance of state vocational school principals in the management of teaching staff. Recapitulation of the results of the three assessments is presented in table 8 .

Table 8. Recapitulation of school supervisors, principals, and teachers' assessment on school principals' performance

\begin{tabular}{|l|l|c|}
\hline No & Assessors & Average score \\
\hline 1 & School Supervisors & 3.91 \\
\hline 2 & Principals & 4.07 \\
\hline 3 & Teachers & 4.10 \\
\hline & Average & 4.05 \\
\hline
\end{tabular}

Source: Primary data

The managerial performance of state vocational school principals in the management of teaching staff in Yogyakarta Special Province is included in the good category with an average score of 4.05 based on the assessment of the three assessment components namely the school supervisors, the teachers, and the school principals themselves. However, based on the results of qualitative research through observation and interviews, there were several constraints or obstacles in the implementation.

Interviews with state vocational school principals indicate some obstacles they experienced in managing teachers and academic staff. Principals have difficulty in the number of teachers available for specific subjects. Subjects like Social Sciences and Pancasila and Civic Education, for example, have limited teachers with a specific degree on the topics even though these subjects are compulsory. Thus, principals should appoint other teachers without an appropriate educational background to teach these subjects. It implies that at some point, the teaching of some subjects was conducted with potentially limited impact for students.

Another obstacle is the certificate of educational professionalism. Ministry of Education and Culture introduced a policy that teachers should have a certificate of teaching. The policy was known as sertifikasi in Indonesia. Teachers with certification will have additional income as an incentive from the government. This certificate guarantees such incentives for teachers with civil 
servant-status or without it. Such an incentive is expected to improve teachers' performance since it comes with some obligation for teachers.

Furthermore, having more teachers with a certificate will also improve school accreditation. However, not all teachers in state vocational high schools have this certificate. It implies that teachers for some subjects may lack the motivation to teach optimally since the income they received is not equal with their peers. For principals, it means additional works to gather potential additional income for teachers without a certificate to ensure all classes were managed optimally.

Principals also face challenges in a limited number of teachers in schools. Ideally, a teacher only teaches certain subjects less than 24 hours a week. However, due to the limited number of teachers in schools, some teachers may teach more than their normal hours. It implies that they have limited free time that can be used to improve teaching quality. Such limitation has roots in minimum financial support to develop teachers' skills. Furthermore, for principals, such a situation provides limited human resources for additional school activities. Principals cannot ask teachers with extra hours a week for activities involving communities or conducted in far areas from schools. Principals have limited options to improve school quality due to limited human resources available.

\section{Discussion}

This study indicates that managerial performance of state vocational school principals based on the assessment by supervisors, school principals, and teachers is considered good. It implies that state vocational school principals in Yogyakarta Special Province have conducted their task in managing teachers and academic staff in accordance with national standards. In general, this finding strengthens previous works on the vocational school that suggest the importance of principal supervision. Principal supervision has been viewed as an important factor behind the achievement of teachers in their creativity (Hidayat, 2019) and performance (Sukayana, Yudana, \& Divayana, 2019). Furthermore, principal performance along with teacher performance also improves student motivation (Putra, 2019) which will lead to better achievement. The finding in this study provides further insight regarding principal evaluation on state vocational schools which in previous works has a limited discussion.

This study collects data from school supervisors, principals, and teachers. School supervisors provide a high score in managerial performance of principals in their capacity in developing a management and utilization program for a teacher in accordance with the vision and mission of the school. This aspect of the performance was scored 4.10 by school supervisors. It indicates that school supervisors believe in principals' capacity in managing a relevant program for teachers. School supervisors in many studies (Nurmala, Murniati AR, \& Bahrun, 2019 and Rachmayani, Murniati AR, \& Nasir, 2019) have significant contributions to improve school quality. Thus, considered being good by school supervision should be important achievement among principals of state vocational schools in Yogyakarta Special Province. 
Principals give a high score for developing an instrument for evaluating teacher performance and carrying out the follow-up of evaluation results. They give these aspects 4.27 which imply their belief in their capacity for creating evaluation instrument and improving quality based on evaluation results. Such finding confirms previous works that emphasize the principal role in managerial performance (Ramli, 2016 and Sakti \& Suroto, 2019). It is important for principals to have faith in their own works because it will affect many aspects of the school environment. Principal transformational leadership in school can lead to better affective commitment among teachers (Tanjung, 2019). The finding of this study contributes to understanding the principal perception of managerial performance in state vocational high schools.

Teachers give high scores on implementing a management and utilization program for the teacher. The score was 4.23 which indicates they benefit the program very well. This finding is important because the good perception among teachers to principal performance can lead to better performance of teachers themselves (Nurdin, 2015 and Anggraeni, 2017). This finding was also in line with Aziz (2019) conclusion on teachers' perception of the principal's supervision. In his research for Islamic teaching teachers, the principal's performance impacts teacher quality in many aspects of learning. Furthermore, Ghifar, Yusuf, Sumardi, \& Wulandari (2019) also emphasize the principal's supervision on teacher creativity which will be crucial for school development as a whole.

This study identifies some obstacles face by principals in managing teachers and academic staff. The main issues rise are the limitation in human resources, certificates, and financial constraints. These findings extend previous research on principal managerial competence in a different area in Indonesia (Slamet $\mathrm{PH}$, (2001; Nasyirwan, 2015; and Handayani, 2016). Principals used to face challenges from the quality of teachers and academic staff especially those without certification from the government. Financial obstacles also became challenges especially in efforts to improve school quality through non-classical activities. Such findings should be considered as a potential improvement that the government should address especially in human resource issues. Vocational education has been prioritized by the government to enhance national competitiveness so that required efforts to maximize its potential is crucial.

\section{Conclusion}

Based on previous results and discussion, this study shows that the managerial performance of state vocational school principals in Yogyakarta Special Province can be considered good. This justification is a summary of the assessment by 10 school supervisors, 15 principals, and 30 teachers involved in daily activities in state vocational school principals in the province. Furthermore, this study also shows the principal's challenges in managing teachers and academic staff such as limited human resources especially teachers with a specific academic degree and teachers with the certificate and limited financial support for teachers' skill improvement. It implies limited activities that the schools can organize to improve school quality. Such challenges should also be considered among 
government responsibilities as mandated by the constitution. Thus, further efforts to optimize the principals' task in managing schools should be supported. This study focuses on the managerial performance of state vocational school principals in Yogyakarta Special Province and obstacles faced in implementing teacher and academic staff management. It has limitations in its limited sample to specific respondents. Further research should improve this limitation by adding larger samples or including more aspects of principals' performance. However, this study provides a unique approach to managerial performance since its questionnaire represents the contribution from school supervisors, principals, and teachers that will ensure a more valid assessment. Furthermore, the questionnaire has been assessed thoroughly so that it has strong validity for further research in the related topics.

\section{References}

Admiraal, W., Janssen, T., Huizenga, J., Kranenburg, F., Taconis, R., \& Corda, A. (2014). E-assessment of student-teachers' competence as new teachers. TOJET: The Turkish Online Journal of Educational Technology, 13(4), 21-29. http:/ / www.tojet.net/articles/v13i4/1343.pdf

Akpan, C.P., \& Ita, A.A. (2015). Teacher professional development and quality universal basic education in Lagos State, Nigeria. Global Journal of Arts, Humanities and Social Sciences, 3(9). Retrieved from http://www.eajournals.org/wpcontent/uploads/Teacher-Professional-Development-and-Quality-UniversalBasic-Education-in-Lagos-State-Nigeria.pdf

Anggraeni, A.D. (2017). Pengaruh persepsi atas kemampuan manajerial kepala sekolah dan budaya organisasi terhadap kinerja guru [Impact of perception on managerial capacity of principal and organization culture towards teacher performance]. Faktor Jurnal Ilmiah Kependidikan, 4(3), 251-264. Retrieved from https://journal.lppmunindra.ac.id/index.php/Faktor/article/view/1922

Azim, S., \& Khan, M. (2012). Authentic assessment: An instructional tool to enhance students learning. Academic Research International, 2(3), 314-320. Retrieved from http:/ / www.savap.org.pk/journals/ARInt./Vol.2(3)/2012(2.3-38).pdf

Aziz, H. (2019). Persepsi guru PAI tentang pelaksanaan supervisi oleh kepala sekolah hubungannya dengan kreativitas guru dalam mengajar (Penelitian guru PAI di SMP se-Kecamatan Cileunyi Kabupaten Bandung) [Perception of Islamic teaching teachers on principal's supervision and teaching creativity (A study in junior high schools in Kecamatan Cileunyi Kabupaten Bandung)]. Al-Murabbi: Jurnal Kependidikan dan Keislaman, 5(2), 185-196. Retrieved from http://ejournal.kopertais4.or.id/mataraman/index.php/murabbi/article/view /3487

Bansal, R. K. (2004). Need for strengthening of internship (rotatory housemanship) training in India. Education for Health, 17(3), 332-338. https:/ / doi.org/ $10.1080 / 13576280400002528$

Bredeson, P. V. (2000) The school principal's role in teacher professional development. Journal of In-Service Education, 26(2), 385-401. https://doi.org/10.1080/13674580000200114

Cizek, G. J. (2000). Pockets of resistance ini the assessment revolution. Educational Measurement Issues and Practice, 19(2), 16-23. https://doi.org/10.1111/j.17453992.2000.tb00026.x

Clark, D. (2009). The performance and competitive effects of school autonomy. Journal of Political Economy, 117(4), 745-783. https://d.oi.org/10.1086/605604 
Darling-Hammond, L. (2000). Teacher quality and student achievement: A review of state policy evidence. Educational Policy Analysis Archives, 8(1).

https://epaa.asu.edu/ojs/article/view/392

Delors, J. (1998). Education for the twenty-first century: Issues and prospects. Paris: UNESCO Publishing.

Devi, V., Devan, D., Soon, P. C., \& Han, W. P. (2012). Comparison of self-directed learning readiness among students experiencing hybrid and traditional curriculum. Journal of Clinical and Diagnostic Research, 6(6), 1047-1050. https://www.jcdr.net/articles/PDF/2323/31\%204084_E(C)_F(T)_PF1(V)_PF(A)_PF(R)_U(P)_2.pdf

Dinas Pendidikan dan Olahraga DIY. (2018). Buku data SMK di Daerah Istimewa Yogyakarta [Vocational schools in Yogyakarta]. Yogyakarta: Disdikpora.

Doherty, G. D. (2008). On quality in education. Journal of Quality Assurance in Education, 16(3), 255-265. https://doi.org/10.1108/09684880810886268

DuFour, R., \& Barkey, T. (2005). The principlal as staff developer. Journal of Development, 16(4), 2-6. https:/ / eric.ed.gov/?id=EJ522301

Fauzi, M., Syafrudin, \& Rokhmat, J. (2018). Principal's managerial skill in improving teachers' performance. IOSR Journal of Research \& Method in Education (IOSRJRME), 8(3), 77-81. Retrieved from http://www.iosrjournals.org/iosrjrme/papers/Vol-8\%20Issue-3/Version-4/M0803047781.pdf

Frey, B. B., Schmitt, V. L., \& Allen, J. P. (2012). Defining authentic classroom assessment. Practical Assessment, Research \& Evaluation, 17(2), 215-232. http:// pareonline.net/pdf/v17n2.pdf

Ghifar, R., Yusuf, A. E., Sumardi, \& Wulandari, F. (2019). Peningkatan kreativitas guru melalui pengembangan supervisi kepala sekolah dan iklim organisasi [Improving teacher quality through principal's supervision and organization climate]. Jurnal Manajemen Pendidikan, 7(2), 790-799. https://doi.org/10.33751/jmp.v7i2.1328

Goetsch, D. L., \& Davis, S. (2014). Quality management for organizational excellence: Introduction to total quality, 7th Edition. Essex: Pearson Education Limited.

Handayani, M. (2016). Pencapaian standar nasional pendidikan berdasarkan hasil akreditasi SMA di Provinsi DKI Jakarta [Achievment of national educational standard based on senior high schools accreditation in Jakarta]. Jurnal Pendidikan dan Kebudayaan, 1(2), 179-201. https:/ / doi.org/10.24832/jpnk.v1i2.766

Hidayat, S. (2019). Supervisi akademik untuk meningkatkan kemampuan guru SMK Kharisma Nusantara Purwakarta dalam membuat perangkat pembelajaran berbasis pemecahan masalah [Academic supervision to improve teachers of SMK Kharisma Nusantara Purwakarta's capacity in creating learning content based on problem-solving]. Syntax Literate: Jurnal Ilmiah Indonesia, 4(9), 141-151. http://dx.doi.org/10.36418/syntax-literate.v4i9.717

Kalolo, J. F. (2015). The quest for quality science education experiences in Tanzanian secondary schools. Journal of Studies in Education, 5(2), 22-39. https://doi.org/ $10.5296 /$ jse.v5 i2.7146

Lauma, I., \& Pido, S. A. T. (2018). Efektivitas pelaksanaan supervisi kepala sekolah terhadap standar proses pembelajaran pendidikan agama Islam di SMK Negeri 1 Kaidipang Kabupaten Bolaang Mongondow Utara [Effectiveness of principal supervision on learning process of Islamic teaching in SMK Negeri 1 Kaidipang Kabupaten Bolaang Mongondow Utara]. Jurnal Ilmiah Al-Jauhari: Jurnal Studi Islam dan Interdisipliner, 3(2), 19-34. https://doi.org/10.30603/jiaj.v3i2.542 
Lee, Y. M., Mann K. V., \& Frank B. W. (2010). What drives students' self-directed learning in a hybrid PBL curriculum. Advances in Health Sciences Education, 15(3), 425-437. https://doi.org/10.1007/s10459-009-9210-2

Listyani, E. (2007). Studi tentang strategi guru dalam pembelajaran matematika menyikapi pergeseran paradigma pendidikan teacher centered ke student centered [Study on teachers' strategies in teaching Mathematics following paradigm shift from teacher-centered to student-centered]. Pythagoras, 3(2), 3850. https://doi.org/10.21831/pg.v3i2.676

Lunenburg, F. C. \& Ornstein, A. C. (2011). Educational administration: Concepts and practices, 6th edition. Singapore: Wadsworth Publishing.

Musiman. (2011). A comparative study between child-centered and teacher-centered in teaching english to elementary school students. Linguistika, 2(2), 1-8. Retrieved from http://jurnal.ubl.ac.id/index.php/Linguistika/article/view/326

Nasution, N. (2013). Pembelajaran efektif [Effective learning]. Jakarta: Media Press.

Nasyirwan (2015). Pencapaian 8 (delapan) standar nasional pendidikan oleh kepala sekolah untuk meningkatkan mutu lulusan [Achievement of eight national educational standards by principals to improve graduate quality]. Manajer Pendidikan, 9(6), 724-736. Retrieved from https://ejournal.unib.ac.id/index.php/manajerpendidikan/article/view/1209/ 0

Nurdin, D. (2015). Kompetensi manajerial kepala sekolah dalam membangun iklim sekolah dan kepuasaan guru di sekolah dasar [Managerial competence of principal to develop school climate and teacher satisfaction in elementary school]. Sekolah Dasar: Kajian Teori dan Praktik Pendidikan, 24(1), 45-56. Retrieved from http://journal2.um.ac.id/index.php/sd/article/view/1352

Nurmala, Murniati, A. R., \& Bahrun (2019). Efektivitas pelaksanaan supervisi oleh pengawas dalam meningkatkan kompetensi profesional guru IPA pada SMP Negeri 3 Ingin Jaya Kabupaten Aceh Besar [Effectiveness of supervision to improve professionalim of Natural Sciences teachers in SMP Negeri 3 Ingin Jaya Kabupaten Aceh Besar]. Jurnal Administrasi Pendidikan, 7(1), 26-34. Retrieved from http://jurnal.unsyiah.ac.id/JAP/article/view/13179

Nye, B., Konstantopoulos, S., \& Hedges, L.V. (2004). How large are teacher effects? Educational Evaluation and Policy Analysis, 26(3), 237-257. https://doi.org/10.3102\%2F01623737026003237

Pranita, U., Kurniah, N., \& Suprapti, A. (2018). Pelaksanaan supervisi klinis kepala sekolah pendidikan anak usia dini Islam terpadu Kota Bengkulu (Studi deskriptif kualitatif di PAUD IT Auladuna Kota Bengkulu) [Implementation of clinical supervision by principal of integrated Islamic early childhood school in Kota Bengkulu (A descriptive qualitative study in PAUD IT Auladuna)]. Jurnal Ilmiah Potensia, 3(1), 54-65. https:// doi.org/10.33369/jip.3.1.54-65

Putra, N. J. (2019). Pengaruh persepsi atas kinerja guru dan kinerja kepala sekolah terhadap motivasi belajar siswa dalam pelajaran PPKn [Impact of perception on teacher performance and principal performance towards student motivation in Pancasila and Civic Subject]. Genta Mulia: Jurnal Ilmiah Pendidikan, 10(1), 84-93. Retrieved from http:/ / ejournal.stkipbbm.ac.id/index.php/gm/article/view/248

Rachmayani, Murniati, A. R., \& Nasir (2019). Strategi pengawas dalam meningkatkan kompetensi pedagogik guru di Madrasah Ibtidaiyah Negeri Bungcala Kabupaten Aceh Besar [Supervisor stretegies to improve teacher pedagogic competence in Madrasah Ibtidaiyah Negeri Bungcala Kabupaten Aceh Besar]. Jurnal Administrasi Pendidikan, 7(1), 21-25. Retrieved from http://jurnal.unsyiah.ac.id/JAP/article/view/13178 
Ramli, E. (2016). Kompetensi pedagogik guru dalam pembelajaran ditinjau dari persepsi kepala sekolah pada sekolah dasar negeri Kota Solok [Teacher pedagogic competence as viewed from principal perception in elementary schools in Kota Solok]. Economix, 4(2), 48-58. Retrieved from https://ojs.unm.ac.id/economix/article/view/8388

Ritchie, J. M. (2013). The effective and reflective principal. Phi Delta Kappan, 94(8), 18-21 https://doi.org/10.1177\%2F003172171309400805.

Robbins, P., \& Alvy, H. (2015). The new principal's fieldbook: Strategies for success. Virginia: ASCD.

Rourke, A. J., \& Coleman, K. S. (2011). Authentic assessment in elearning: Reflective and Collaborative writing in the arts. In Proceedings of ASCILITE - Australian Society for Computers in Learning in Tertiary Education Annual Conference 2011 (pp. 10891095). Australasian Society for Computers in Learning in Tertiary Education. Retrieved from https://www.learntechlib.org/p/43660/

Rudatin, R. M. D. (2015). Dari teacher centered leraning menuju student centered learning (Studi kasus tentang proses pembelajaran di SMAN 1 Manyaran) [From teacher-centerd learning to student-centered learning (A case study on learning process in SMAN 1 Manyaran)]. Sosialitas, 5(2), Retrieved from https://jurnal.fkip.uns.ac.id/index.php/sosant/article/view/6406

Sakti, B. J. P., \& Suroto (2019). Persepsi kepala sekolah dan pengawas terhadap kinerja guru PJOK (Studi pada sekolah menengah pertama negeri se-Kota Blitar tahun ajaran 2017/2018) [Perception of principal and supervisor towards sport teacher performance in junior high schools in Kota Blitar academic year 2017/2018]. Jurnal Pendidikan Olahraga dan Kesehatan, 7(2), 175-181. Retrieved from https://jurnalmahasiswa.unesa.ac.id/index.php/jurnal-pendidikanjasmani/article/view/27203

Schacter, J. (2006). Teacher performance-based accountability: Why, what and how. Santa Moica: Miken Family Foundation. Retrieved from http://www.mff.org/pubs/ performance-assessment.pdf

Scholtz, A. (2007). An analysis of the impact of an authentic assessment strategy on student performance in a technology-mediated constructivist classroom: A study revisited. International Journal of Education and Development using ICT, 3(4), 42-53. Retrieved from https://www.learntechlib.org/p/42221/

Slamet, P. H. (2001). Karakteristik kepala sekolah tangguh. Jurnal Pendidikan dan Kebudayaan, 6(25), 319-333.

Stanley, J. M. (2016). Strategic planning for public and nonprofit organizations, 3rd edition. San Fransisco: Jossey-Bass Publishers.

Subekhi, A., \& Jauhar, M. (2012). Pengantar manajemen sumber daya manusia (MSDM) [Introduction to human resources management]. Jakarta: Prestasi Pustaka.

Sugiyo, W., Kusuma, E., \& Wahyuni, P.T. (2009). Efektivitas metode student centered learning yang berbasis fun chemistry untuk meningkatkan hasil belajar kimia siswa [Effectiveness of fun chemistry-based student-centered learning method to improve learning outcome of students in Chemsitry]. Jurnal Inovasi Pendidikan Kimia, 3(2), 469-475. Retrieved from https://journal.unnes.ac.id/nju/index.php/JIPK/article/view/1283

Sukayana, I.., Yudana, M., \& Divayana, D. G. H. (2019). Kontribusi kepemimpinan transformasional, supervisi akademik kepala sekolah, kompetensi pedagogik dan motivasi kerja terhadap kinerja guru di SMK Kertha Wisata Denpasar [Impact of transformational leadership, principal academic supervision, pedagogic competence, and work motivation towards teacher performance in 
SMK Kertha Wisata Denpasar]. Jurnal Administrasi Pendidikan Indonesia, 10(2), 157-162. https://doi.org/10.23887/japi.v10i2.2804

Suyanto \& Jihad, A. (2013). Menjadi guru professional: Strategi meningkatkan kualifikasi dan kualitas guru di era global [On being a professional teacher: Strategies to improve teacher's qualification and quality in global era]. Jakarta: Erlangga Group.

Syahrul. (2016). Kepemimpinan kepala sekolah: Sebuah tantangan manajerial satuan pendidikan [Principal leadership: A managerial challenge for educational unit]. Makasar: Graha Prima Alinea.

Tanjung, A. (2019). Pengaruh persepsi kepemimpinan transformasional kepala sekolah, budaya sekolah dan motivasi berprestasi terhadap komitmen afektif guru SMP Negeri di wilayah Tanjung Morawa Kabupaten Deli Serdang [Impact of principal perception on transformational leadership, school culture, and motivation towards affective commitment of teachers in junior high schools in Tanjung Morawa Kabupaten Deli Serdang]. Wahana Inovasi: Jurnal Penelitian dan Pengabdian Masyarakat UISU, 8(1), 111-123. Retrieved from https://jurnal.uisu.ac.id/index.php/wahana/article/view/1450

Trinova, Z. (2013). Pembelajaran berbasis student-centered learning pada materi pendidikan agama Islam [Learning activities in a student-centered class for Islamic teaching]. Al-Ta'lim, 20(1), 324-335. Retrieved from http://www.journal.tarbiyahiainib.ac.id/index.php/attalim/article/view/28 